\title{
Christoph Schönborn
}

\section{Odnajdywanie zamysłu w przyrodzie *}

Od roku 1996, w którym Papież Jan Paweł II powiedział, że ewolucja (termin, którego bliżej nie zdefiniował) jest „czymś więcej niż hipotezą", obrońcy dogmatu neodarwinowskiego często powoływali się na rzekomą akceptację, względnie zgodę kościoła rzymsko-katolickiego, broniąc swojej teorii, jako możliwej do pogodzenia w jakiś sposób z wiarą chrześcijańską.

Ale to nieprawda. Kościół Katolicki, pozostawiając dociekaniom przyrodniczym wiele szczegółów związanych $\mathrm{z}$ historią życia na Ziemi, głosi, że w świetle rozumu, intelekt ludzki może łatwo i wyraźnie rozpoznać celowość i zamysł w świecie natury, do którego należy świat istot żywych.

Idea ewolucji, jeśli ją rozumieć jako pochodzenie od wspólnego przodka, może być prawdziwa, lecz rozumiana w sensie neodarwinowskim jako niekierowany i nieplanowany proces powstawania przypadkowych zmian i naturalnej selekcji nie może być prawdziwa. Każdy system poglądów, który stawia sobie za zadanie zaprzeczenie lub zaproponowanie wyjaśnienia pomijającego przytłaczające dowody na rzecz projektu widocznego w świecie istot żywych jest ideologią, a nie nauką.

"Christoph SchönBorn, „Finding Design in Nature”, The New York Times, July 7, 2005, http://www.nytimes.com/2005/07/07/opinion/07schonborn.html. Z języka angielskiego za zgodą Autora przełożył Piotr Lenartowicz SJ. Recenzent: Józef Zon, Katedra Biologii Teoretycznej Katolickiego Uniwersytetu Lubelskiego. 
Rozważmy to, czego naprawdę nauczał nasz ukochany Jan Paweł. Mimo, że jego ogólnikowy i drugorzędny list na temat ewolucji stale i wszędzie jest cytowany, nie widać, aby ktoś zastanawiał się nad tymi jego komentarzami, które Papież wygłaszał od roku 1985, a które przedstawiają $\mathrm{z}$ całą wyrazistością jego nauczanie $\mathrm{w}$ sprawach dotyczących Przyrody.

Wszystkie obserwacje dotyczące rozwoju życia prowadzą do podobnych konkluzji. Ewolucja form żywych, której etapy i mechanizmy bada przyrodoznawstwo, ujawnia zachwycającą wewnętrzną celowość. Ta celowość, która kieruje tymi bytami bez ich udziału i bez wpływu z ich strony, skłania człowieka do przypuszczeń o istnieniu Umysłu, który jest ich wynalazcą, ich stwórcą.

A dalej Papież stwierdza:

Tym wszystkim wskazówkom istnienia Boga Stwórcy niektórzy przeciwstawiają moc przypadku lub mechanizmów właściwych materii. Mówienie o przypadku $\mathrm{w}$ Kosmosie, który jest tak bardzo złożony w swoich elementach i tak cudownie celowy w swoim [dynamizmie] życia, oznaczałoby rezygnację z poszukiwania wyjaśnienia tego, co w tym świecie dostrzegamy. Byłoby to uznanie skutków bez przyczyny. Byłaby to abdykacja naszej ludzkiej inteligencji, wyrzekającej się poszukiwań i dążenia do rozwiązywania problemów.

Należy zwrócić uwagę na to, że słowo „celowość” jest terminem filozoficznym, synonimem przyczyny celowej, ukierunkowania, projektu. Rok później, podczas audiencji generalnej Jan Paweł dochodzi do wniosku, że ,prawda wiary o stworzeniu z całą oczywistością radykalnie przeciwstawia się teoriom filozofii materialistycznej. Te bowiem uznają kosmos jako rezultat ewolucji materii, redukowalny do czystego przypadku i konieczności”.

Oczywiście, zgadza się to z autorytatywnym tekstem Katechizmu Kościoła Katolickiego: „Ludzka inteligencja jest niewątpliwie zdolna 
do odpowiedzi na pytanie dotyczące początków. Istnienie Boga Stwórcy może być bezbłędnie poznane poprzez Jego dzieła, przy pomocy światła ludzkiego rozumu”. Katechizm dodaje, że: „Bóg, jak wierzymy, stworzył świat w sposób rozumny. Nie jest on produktem żadnej konieczności ani ślepego losu lub przypadku."

W żałosnym nowym zwrocie starej kontrowersji neodarwiniści starają się ostatnio przedstawiać nowego Papieża, Benedykta XVI, jako zwolennika ewolucji. Cytują pewne zdanie, dotyczące wspólnego pokrewieństwa, a pochodzące z dokumentu wydanego w 2004 roku przez Międzynarodową Komisję Teologiczną. Przypominając, że Benedykt był w tym czasie przewodniczącym tej komisji dochodzą do wniosku, że Kościół Katolicki nie ma żadnych zastrzeżeń do „ewolucji” w powszechnym dla biologów rozumieniu tego słowa, czyli w sensie synonimu teorii neodarwinizmu.

Jednak dokument komisji potwierdza odwieczne nauczanie Kościoła Katolickiego co do rzeczywistości zamysłu w przyrodzie. W komentarzu dotyczącym licznych zniekształceń znaczenia listu Jana Pawła o ewolucji z roku 1996, komisja przestrzega przed „używaniem tego listu jako przykrywki dla aprobaty wszystkich teorii ewolucji, włączając w nie teorie neodarwinowskiej proweniencji, które explicite zaprzeczają, by Opatrzność Boża miała jakąkolwiek przyczynową rolę w rozwoju życia w Kosmosie.

Co więcej, zdaniem komisji „Bezkierunkowy proces ewolucji wykraczający poza granice Bożej Opatrzności - nie może po prostu zaistnieć”.

Podczas swej intronizacji, parę tygodni temu, Benedykt ogłosił, że: „Nie jesteśmy jakimś przypadkowym i bezsensownym produktem ewolucji. Każdy z nas jest wyrazem myśli Bożej. Każdy z nas stał się upragnionym, ukochanym i wręcz koniecznym".

Poprzez swą historię kościół bronił prawd wiary danej nam przez Jezusa Chrystusa. Jednak w epoce nowożytnej Kościół Katolicki stał się w zadziwiający sposób bastionem, broniącym również samego ro- 
zumu. W XIX wieku Pierwszy Sobór Watykański pouczał świat, świeżo zauroczony ,śmiercią Boga”, że ludzkość samym rozumem jest w stanie poznać rzeczywistość Przyczyny Pierwszej, Pierwszego Poruszyciela, „Boga filozofów”.

Obecnie, na początku XXI stulecia, w obliczu roszczeń neodarwinizmu i wielorakich hipotez kosmologicznych, wymyślonych po to, by zignorować ogromną oczywistość celowości i projektu odnalezioną przez nowoczesną wiedzę przyrodniczą, Kościół Katolicki znowu będzie bronił ludzkiego rozumu głosząc, że wewnętrzny zamysł dostrzegany $\mathrm{w}$ przyrodzie nie jest złudzeniem. Teorie przyrodnicze, które usiłują wymknąć się tej oczywistości projektu przywołując działanie „przypadku i konieczności” nie są wcale naukowe, lecz, jak to ujął Jan Paweł, są kapitulacją ludzkiej inteligencji.

Christoph Schönborn 